\title{
DETERMINAN PROFIT DISTRIBUTION MANAGEMENT BANK SYARIAH DI INDONESIA PERIODE 2008-2011
}

\author{
Gagat Panggah Mulyo \\ Siti Mutmainah \\ Universitas Diponegoro, Semarang \\ Email: titikhasyim@yahoo.com
}

\begin{abstract}
Abstrak: Determinan Profit Distribution Management Bank Syariah di Indonesia Periode 2008-2011. Studi ini bertujuan menganalisa faktor-faktor yang mempengaruhi manajemen distribusi laba (PDM) in bank syariah Indonesia. Koleksi data dilakukan dengan metode purposive sampling dari 5 bank (Bank Muamalat, Bank Syariah Mandiri, Bank Mega Syariah, Bank Bukopin Syariah dan Bank Rakyat Indonesia Syariah). Hasil mengndikasikan bahwa kecukupan modal, proporsi pendanaan non investasi, eliminasi penghapusan aset produktif, memiliki pengaruh positif pada PDM. Efektivitas pendaanaan depositor dan proporsi pendanaan depositir memiliki pengaruh negatif pada PDM, sedangkan pertumbuhan Produk Domestik Bruto dan umur bank tidak memiliki pengaruh pada PDM.
\end{abstract}

\begin{abstract}
Profit Distribution Management Determinants of Shariah Banks in Indonesia 2008-2011. This study aims to analyze the factors influencing the profit distribution management (PDM) in shari'ah banks in Indonesia. Data collected by purposive sampling method from 5 banks (Bank Muamalat, Bank Syariah Mandiri, Bank Mega Syariah, Bank Bukopin Syariah dan Bank Rakyat Indonesia Syariah). Theresultsindicated that capital adequacy, proportion of non investing financing, elimination of productive asset deletion have positive effect on the Profit Distribution Management. Effectiveness of depositors' funding and proportion of depositors' funding have negative effect on PDM, while growth of gross domestic product and bank age do not have effect on PDM.
\end{abstract}

Kata kunci: profit distribution management, profit loss sharing, depositor, depositors' funding, Islamic bank.

Profit distribution (PD) adalah pembagian keuntungan bank syariah kepada deposan berdasarkan nisbah yang disepakati setiap bulannya. PDdiatur berdasarkan produk yang menjadi pilihan deposan terhadap bank, serta persetujuan nisbahnya. Pihak manajemen bank syariah harus memperhatikan betul tingkat PDmelalui pengelolaannya (profit distributionmanagement). Profit Distribution Management (PDM)dapat diartikan sebagai aktivitas yang dilakukan manajer dalam mengelola pendistribusian laba untuk memenuhi kewajiban bagi hasil bank syariah kepada deposannya.

Penelitian tentang PD telah dilakukan oleh para peneliti baik dari luar maupun dalam negeri. Penelitian yang dilakukan Sundararajan (2005) dalam Farook et al. (2009) menemukan bahwa bank syariah yang menjadi sampel penelitiannya melakukan PDM yang mengacu pada suku bunga dan memiliki fleksibilitas secara implisit dalam pengelolaan PDM dengan cara mengubah management fee. Sundararajan (2005) dalam Farook et al.(2009) menyatakan bahwa bank syariah melakukan PDM berdasarkan hubungan yang kuat antara suku bunga pasar dan distribusi bagi hasil deposannya dalam sampel penelitiannya. Hal tersebut Sundararajan (2005) perkuat dengan ditemukannya hubungan tidak

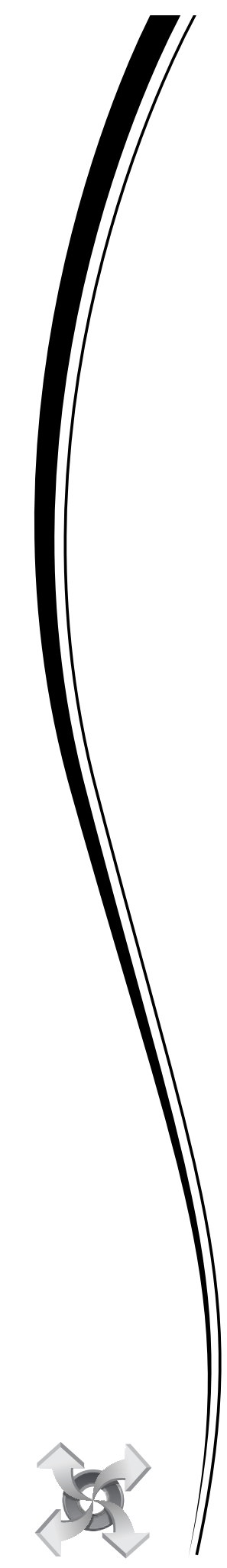

Jurnal Ekonomi, Manajemen dan Akuntansi Islam I M A NEN S I Volume 1 Nomor 1 Halaman 1-74 Malang, September 2013 ISSN 2339-1847 
signifikan antara asset returns dan distribusi bagi hasil deposannya(dalam Farook et al., 2009).

Di Indonesia, bisa jadi manajer bank syariah melakukan PDM yang mengacu pada suku bunga bank konvensional. Hal ini terkait erat dengan tipe deposan di Indonesia. Deposan bank syariah di Indonesia terbagi dalam beberapa segmentasi pasar. Karim dan Afif (2006) menyatakan bahwa di Indonesia ditemukan tiga segmentasi pasar, yaitu sharia loyalist (terdiri dari penganut agama yang patuh), floating segment (kombinasi agama dan kekuatan pasar) dan conventional loyalist. Di Indonesia, penelitian yang dilakukan oleh Khairunnisa (2001) menemukan bahwa deposan mengincar profit maximization. Survey dari Karim (2003) juga menyebutkan bahwa $70 \%$ deposan perbankan syariah adalah deposan yang berada pada floating segment, yang sensitif pada tingkat keuntungan. Penelitian Husnelly (2003) dan Mangkuto (2004) juga menegaskan bahwa faktor yang menjadi pertimbangan masyarakat menginvestasikan dananya di bank syariah adalah faktor return bagi hasil. Penelitian terdahulu menunjukkan bahwa perilaku menabung di bank syariah paling dipengaruhi oleh tingkat bagi hasil(profit distribution). Hasil penelitian tersebut memberi implikasi bahwa sangatlah penting bagi bank syariah untuk menjaga kualitas tingkat PD. Deposan akan selalu memperhatikan dan memperhitungkan tingkat bagi hasil yang diperoleh dalam investasi pada bank syariah. Logikanya jika tingkat bagi hasil terlalu rendah daripada bank lain terutama dibanding dengan suku bunga bank konvensional, maka tingkat kepuasan deposan akan menurun dan kemungkinan besar deposan akan memindahkan dananya pada bank lain (displacement fund). Secara tidak langsung bank syariah dituntut untuk melakukan profit distribution managementyang mengacu pada suku bunga.

Beranjak dari penelitian Sundararajan (2005), Farook et al. (2009) meneliti tentang PDM yang mengacu pada suku bunga di beberapa negara.Farook et al. (2009) menggunakan profit distribution management sebagai variabel dependen, kemudian faktor eksternal dan internal bank sebagai variabel independen dalam penelitiannya. Farook et al. (2009) menemukan bahwa bank syariah di beberapa negara (sampel penelitian) khususnya di Indonesia, memiliki rata-rata PDM yang tinggi, tetapi sampel bank syariah yang diambil dari Indonesia hanya ada dua, yaitu Bank Muamalat Indonesia dan Bank Syariah Mandiri.

Berbeda dengan Farook et al. (2009), penelitian ini menggunakan laporan keuangan triwulanan dari periode triwulan IV2008 hingga periode triwulan III-2011. Dipilihnya periode 2008 dikarenakan pemerintah menerbitkan UU No.21 tahun 2008 tentang Perbankan Syariah. Penerbitan UU No. 21 tahun 2008 tersebut pastinya akan berdampak pada perkembangan bank syariah di Indonesia. Penelitian ini pun tidak menggunakan seluruhvariabel independen dari penelitian Farook et al. (2009). Hal ini dilakukan karena adanya keterbatasan data yang harus disesuaikan dengan periode triwulanan dan data-data yang tidak dapat didapatkan. Sebagai tambahan untuk variabel independen, dalam penelitian ini akan digunakan variabel rasio keuangan yang dinilai berpengaruh terhadap PD dari penelitian-penelitian dalam negeri, yaitudari penelitian Mawardi (2005), Vustany (2006), Azmy (2009) dan Aisiyah (2010). Penelitianpenelitian tersebut memberikan hasil yang beragam.

Berdasarkan uraian di atas, maka penelitian ini dilakukan untuk menguji faktor-faktor yang mempengaruhi tingkat profit distribution managementyang mengacu pada suku bungaatas simpanan deposan bank syariah pada periode 2008-2011 di Indonesia. Adapun pertanyaan penelitian yang muncul adalah: apapengaruh kecukupan modal, efektivitas dana pihak ketiga, risiko pembiayaan, pertumbuhan produk domestik bruto, proporsi pembiayaan non investasi, proporsi dana pihak ketiga, penyisihan penghapusan aktiva produktif dan umur bankterhadapprofit distribution management?Kontribusi yang diharapkan dari penelitian ini setidak-tidaknya adalah: (1) dapat menjadi pertimbangan bagi perbankan syariah untuk meningkatkan kinerjanya dengan lebih baik dengan didasarkan pada negara dan syariah Islam, (2) dapat memberikan informasi tentang faktor-faktor yang mempengaruhi profit distribution management kepada deposan dan investor.

Stakeholder dibagi menjadi dua yaitu stakeholder primer dan sekunder (Brooks 2004) didasarkan pada legalitas, urgensi dan power yang dimilikinya. Stakeholder primer berarti individu atau kelompok yang tanpa keberadaannya perusahaan tidak 
mampu survive untuk going concern. Stakeholder sekunder merupakan individu atau kelompok yang mempengaruhi dan dipengaruhi perusahaan, namun mereka tidak berhubungan dengan transaksi dengan perusahaan dan tidak esensial kelangsungannya.

Dalam kaitannya dengan bank, terutama bank syariah yang berada dalam lingkungan dual banking system, nasabah simpanan (deposan) dan bank-bank pesaing menjadi stakeholder primer dan sekunder yang keberadaannya sangat berpengaruh bagi jalannya operasi bank. Bagi bank, deposan merupakan keberadaan yang vital, karena bank membutuhkan dana dari deposan sebagai salah satu fungsi operasional bank untuk going concern dalam bentuk tabungan, deposito dan giro. Hal tersebut mengakibatkan setiap bank (bank syariah ataupun bank konvensional) untuk bersaing memperoleh pangsa pasar deposan, dimana bank konvensional menggunakan suku bunga dan bank syariah dengan sistem bagi hasilnya untuk menarik deposan.

Tipe deposan di Indonesia sebagian besar termasuk dalam kelompok floating segment (Karim2003; Khairunnisa2001; Husnelly dan Mangkuto 2004; Andriyanti dan Wasilah 2010). Dalam segmen ini sangat tinggi kemungkinan terjadinya displacement fund karena perbedaan return antara bank konvensional dan bank syariah. Jika bank konvensional yang mengacu pada $B I$ rate memiliki tingkat return yang lebih tinggi, maka bank syariah terpaksa (forced) melakukan Profit Distribution Management (PDM) yang mengacu pada suku bunga (BI rate), sehingga tingkat return bagi hasildi bank syariah tidak kalah bersaing. Oleh karena itu, PDM menjadi salah satu langkah yang digunakan manajer bank syariah untuk memanagestakeholder-nya dan bersaing dengan bank yang lain.

Banyak terdapat definisi mengenaiProfit Distribution (PD). Ada yang menerjemahkan PD sebagai distribusi hasil usaha, distribusi pendapatan (Mawardi 2005) dan distribusi bagi hasil (Antonio 2001). Distribusi hasil usaha adalah perhitungan pembagian usaha antara shahibul maal dengan mudharib sesuai dengan nisbah yang disepakati awal akad. Menurut Antonio (2001), metode distribusi bagi hasil merupakan faktor tidak langsung dalam menentukan besarnya bagi hasil yang akan dibagikan. Menurut Agustianto (2008), bagi hasil adalah keuntungan/ hasil yang diperoleh dari pengelolaan dana baik investasi maupun transaksi jual beli yang diberikan kepada nasabah. Menurut Bank Indonesia (n. D.), distribusi bagi hasil adalah pembagian keuntungan bank syariah kepada nasabah simpanan berdasarkan nisbah yang disepakati setiap bulannya. Jadi bisa disimpulkan secara singkatprofit distribution managementmerupakan aktivitas yang dilakukan manajer dalam mengelola pendistribusian laba untuk memenuhi kewajiban bagi hasil bank syariah kepada nasabahnya.

Kecukupan modal menggambarkan kemampuan bank dalam mempertahankan modal yang mencukupi untuk menutup risiko kerugian yang mungkin timbul dari penanaman danadalam aset produktif yang mengandung risiko, serta untuk pembiayaan dalam aset tetap dan investasi.Capital Adequacy Ratio (CAR) dapat digunakan untuk mengukur kecukupan modal pada bank syariah (Muhammad 2005). Semakin besar rasio ini, maka kesehatan bank dikatakan membaik. Hal ini dikarenakan besar modal yang dimiliki bank mampu menutupi risiko kerugian yang timbul dari penanaman dana dalam aset produktif yang mengandung risiko, serta dapat digunakan untuk pembiayaan penanaman dalam aset tetap dan investasi. Berdasarkan ketentuan Bank for International Settlements, bank yang dinyatakan sebagai bank sehat harus memiliki CAR paling sedikit sebesar 8\% (Muhammad 2005: 249).

CAR yang tinggi membuat bank mampu meredam risiko-risiko yang muncul, sehingga manajer bank lebih berani melakukan PDM yang mengacu pada suku bunga dikarenakan bank sedang dalam kondisi yang aman. Jika dikaitkan dengan teori stakeholder, bank syariah akan meningkatkan PDM yang mengacu pada suku bunga untuk memuaskandeposannya.

Efektivitas dana pihak ketiga (EDPK) merupakan cerminan dari fungsi intermediasi bank, yaitu dalam menyalurkandana pihak ketiga ke pembiayaan. EDPK dapat diukur dengan Financing to Deposit Ratio(FDR). Semakin tinggi rasio ini (menurut Bank Indonesia $85 \%-100 \%$ ), semakin baik tingkat kesehatan bank, karena pembiayaan yang disalurkan bank lancar, sehingga pendapatan bank semakin meningkat.

Mempertahankan likuiditas yang tinggi akan memperlancar customer relationship tetapi tingkat bagi hasil akan menurun karena banyaknya dana yang menganggur. 
Dilain pihak likuiditas yang rendah menggambarkan kurang baiknya posisi likuiditas suatu bank. Karena itu apabila EDPK yang diukur dengan rasio FDR semakin tinggi, maka bagi hasil akan semakin tinggi juga. Hal tersebut bila dikaitkan dengan teori stakeholder, maka bank syariah akan mengurangi tingkat PDMyang mengacu pada suku bunga. Berkurangnya tingkat PDM dikarenakan bank telah mampu memanage deposannya dengan tingkat PD yang sudah tinggi.

Risiko pembiayaan (RP) digunakan untuk mengukur tingkat permasalahan pembiayaan yang dihadapi oleh bank syariah. RP dapat diukur dengan Non Performing Financing (NPF). NPF merupakan rasio untuk mengukur kemampuan bank dalam menjaga risiko kegagalan pengembalian kredit oleh debitur. Semakin tinggi rasio ini, menunjukkan kualitas pembiayaan bank syariah yang semakin buruk. Bank Indonesia melalui Surat Edaran Bank Indonesia No.6/23/DPNP tanggal 31 Mei 2004 menetapkan kriteria rasio NPL yang ideal di bawah $6 \%$.

Semakin baik kualitas pembiayaan yang disalurkan bank, makin kecil tingkat NPF. Apabila RP semakin besar, maka bagi hasil semakin rendah. Bila dikaitkan dengan teori stakeholder, maka bank syariah akan menaikan tingkatPDMyang mengacu pada suku bunga untuk memuaskan/memanage deposannya. Bertambahnya tingkat PDM dikarenakan tingkat PD yang diperoleh deposan sudah rendah.

Produk domestik bruto (PDB) merupakan alat ukur utama tingkat kesejahteraan ekonomi suatu negara. Pertumbuhan PDB dicerminkan dengan adanya kenaikan antara PDB mendatang dengan PDB periode sebelumnya. Kondisi perekonomian yang baik menandakan kegiatan produksi dalam negeri sehat dan dicerminkan oleh pertumbuhan PDB di setiap waktu. Ketika terjadi hal yang sebaliknya yaitu kondisi perekonomian negara yang buruk seperti resesi, maka akan terjadi peningkatan tingkat pengangguran dan penurunan dalam pertumbuhan bisnis.

Dalam resesi terdapat kemungkinan bahwa individu maupun pebisnis akan kesulitan atau bahkan tidak mampu memenuhi kewajiban membayar hutang kepada bank (Farook et al. 2009). Akibatnya, aset yang didanai oleh deposan (Investment Account Holder/IAH) akan memiliki kinerja yang memburuk. Bila dikaitkan dengan teori stakeholder dimana bank harus memanage deposannya, maka bank syariah akan mengorbankan laba mereka sendiri atau bahkan modal pemegang saham untuk mempertahankan competitive return kepada IAH. Saatsaat itulah bank syariah akan melakukan PDM yang mengacu pada suku bunga ( $\mathrm{Fa}-$ rooket al. 2009).

Proporsi pembiayaan Non Investasi (PPNI) bank syariah mengacu pada pembiayaan dengan tingkat tetap (sisi piutang). Pembiayaan Non Investasi pada bank syariah dilakukan dengan akad Murabahah, Salam, Istishna' dan Ijarah. Biasanya instrumen tersebut berada dalam jangka waktu 3 bulan hingga 8 tahun. Pembiayaan jenis ini menggunakan tingkat harga dan keuntungan yang disepakati di awal kontrak. Selama kontrak ini berjalan dan pembayaran diangsur, waktu semakin berjalan. Saat berjalannya waktu, terdapat kemungkinan terjadi perubahan tingkat suku bunga, sehingga bank syariah berhadapan dengan fund gap antara asset returns yang sudah ditetapkan di awal kontrak dengan dana deposan yang digunakan untuk proses pembiayaan non investasi tersebut.

Deposan sebagai pemilik dana yang tergolong dalam floating segment akan sangat sensitif terhadap perubahan tingkat suku bunga, mereka berharap mendapat return yang tidak kalah menariknya dari bank lain. Kenyataannya dana mereka digunakan oleh bank untuk pembiayaan non investasi yang tergolong menggunakan tingkat harga dan keutungan yang tetap yang telah disepakati di awal kontrak. Hal ini dinamakan profit rate risk. Besarnya PPNImenentukan tingkat dimana bank syariah melakukan PDM untuk return mismatchdalam keadaan pasar dimana terdapat perubahan suku bunga (Farook et al. 2009). Oleh karena itu, semakin tinggi tingkat rasio, semakin tinggi tingkat PDM. Hasil penelitian Farook et al. (2009) menemukan bahwaloan asset to total asset(LATA) berhubungan positif dengan tingkat profit distribution management.

Proporsi dana pihak ketiga (PDPK) merupakan variabel yang menggambarkan seberapa besar kebergantungan bank terhadap dana deposan. Dana merupakan masalah utama bagi bank sebagai lembaga keuangan, karena dana yang dihimpun dari masyarakat ternyata merupakan dana terbesar yang paling diandalkan oleh bank. Jika dana tidak cukup, bank tidak mampu melakukan fungsinya dengan maksimal atau bahkan menjadi tidak berfungsi sama 
sekali. PDPK merupakan proksi yang menggambarkan seberapa besar ketergantungan bank terhadap dana pihak ketiga.

Farooket al. (2009) juga berpendapat bahwa bank syariah dengan proporsi dana pihak ketiga yang lebih kecil daripada dana pemegang saham cenderung tidak mengelola PDM yang mengacu pada suku bunga. Bank syariah tersebut kemungkinan lebih menyediakan PDM yang bersifat konsisten sesuai dengan asset returns yang diperoleh. Hal tersebut bila dikaitkan dengan teori stakeholder dimana bank akanme-manage deposannya, maka tingkat PDM pun meningkat seiring meningkatnya PDPK.

Bank memiliki suatu kebijakan cadangan, kebijakan tersebut mengacu pada penyisihan kerugian. Bank syariah memiliki kecenderungan untuk membentuk penyisihan kerugian untuk menyerap kerugian di masa depan (Boulila dkk. 2010).

Besarnya penyisihan dalam batasann persentase tertentu ditentukan oleh Bank Indonesia, namun pihak manajemen bank masih diberikan keleluasaan untuk menentukan kualitas aset berdasarkan ketentuan yang diatur dalam PBI tersebutserta membentuk cadangan PPAP melebihi cadangan yang wajib dibentuk. Oleh karenanya seringkali PPAP dijadikan objek oleh manajar dalam melakukan manipulasi laba (Tobing dan Anggorowati 2009). Konsekuensinya, PPAP ini mendorong bank untuk lebih berani dalam mengambil risiko dalam melakukan pembiayaan karena tahu bahwa PD ke nasabah terlindungi. Terdapat kemungkinan bahwa bank syariah lebih nyaman melakukan PDM jika terdapat cadangan tersebut (Farook et al.2009).

Menurut Farook et al. (2009),dalam konteks bank, bank yang baru berdiri sama dengan perusahaan yang baru berdiri. Bank yang baru berdiri tersebut memiliki kekurangan informasi mengenai kondisi bank itu sendiri. Bank yang baru berdiri harus mampu melakukan tindakan yang membangun kepercayaan bagi para stakeholdernya.Farook et al. (2009) berpendapat bahwa susah bagi perusahaan untuk memulai operasi usahanya terutama mendapatkan laba di awal-awal tahun operasinya. Bagi bank syariah ini merupakan hal yang buruk terutama karena penggunaan sistem bagi hasil. Susahnya mendapatkan laba akan membuat bagi hasil semakin kecil, hal ini akan mengakibatkan deposan menarik dananya dan memindahkannya pada bank yang memberikan return lebih baik (displacement fund). Bila dikaitkan dengan teori stakeholder, maka demi mengurangi risiko ini, bank syariah akan menjaga atau meningkatkan tingkat PDM untuk membangun kepercayaan atas deposannya.

\section{METODE}

Profit distribution management merupakan variabel dependen dalam penelitian ini. PDM menggambarkan tingkat dimana bank melakukan kewajibannya dalam membagi keuntungan dari hasil usaha kepada deposan simpanan sebagai pemilik modal. Dalam penelitian ini bank syariah melakukan PDM yang mengacu pada suku bunga. Berdasarkan model penelitian Farook dkk. (2009), penelitian ini menggunakan asset spread sebagai metode untuk menghitung PDM yang mengacu pada suku bunga. Asset spread adalah absolute spread antara Return On Asset (ROA) dan average Return On Investment Account Holder(ROIAH) yang merupakan rata-rata return bagi hasil deposan. Asset Spread dapat dirumuskan pada rumus (1):

Rata-rata ROIAH dapat dihitung dengan menggunakan "total pendapatan yang harus dibagi" dibagi dengan "saldo rata-rata instrumen bagi hasil deposan". Kedua item tersebut dapat dilihat pada Laporan Distribusi Bagi Hasil, rumus (2).

Asset Spread merupakan indikator paling kuat untuk menghitung PDM. Asset spread mempertimbangkan seluruh pendapatan dan beban dan menyediakan spread antara total assetreturn dari aset bank dan distribusi yang diberikan kepada deposan. Semakin tinggi asset spread mengindikasikan adanya pendistribusian laba kepada deposan yang jauh dari asset return. Hal tersebut memperkuat adanya tindakan PDM yang mengacu pada suku bunga sesuai dengan penelitian Sundararajan (2005) dan Farook et al.(2009).

Kecukupan Modaldiukur dengan rasio CAR. Rasio CAR pada bank syariah dihitung dengan perbandingan antara modal sendiri terdiri dari modal inti dan modal pelengkap (maksimal 100\% dari modal inti) dibanding dengan aset tertimbang menurut risiko $(\mathrm{Mu}-$ hammad, 2009). CAR diperoleh dari modal bank dibagi dengan total Aset Tertimbang Menurut Risiko (ATMR), sehingga dirumuskan dalam rumus (3):

Efektivitas Dana Pihak Ketiga (EDPK) dapat diukur dengan rasio FDR. FDR dalam penelitian ini diukur menggunakan skala 
pengukuran rasio yang ada pada laporan keuangan bank syariah. FDR dirumuskan dalam rumus (4) (Mawardi 2005):

Risiko Pembiayaan (RP) dapat diukur dengan rasio NPF. NPF merupakan rasio untuk mengukur kemampuan bank dalam menjaga risiko kegagalan pengembalian pembiayaan oleh debitur. NPF dirumuskan dalam rumus (5) (Mawardi 2005):

PDB digunakan sebagai alat ukur utama tingkat kesejahteraan ekonomi suatu negara. PDB mampu mengukur kemampuan dari suatu negara untuk memperbesar outputnya dalam laju yang lebih cepat daripada tingkat pertumbuhan penduduknya (Nasution, 2009). PPDB dirumuskan dalam rumus (6) (Farook et al. 2009):

Proporsi Pembiayaan Non Investasi (PPNI) dapat diukur dengan rasio LATA. LATA dapat dihitung dari persentase loan asset sebagai proporsi dari total asset. LATA dirumuskan dalam rumus (7) (Farook et al. 2009):

PDPK merupakan variabel yang menggambarkan seberapa proporsi dana pihak ketiga bank. PDPK dirumuskan dalam rumus (8) (Farook et al. 2009):
Kebijakan cadangan mengacu pada penyisihan kerugian. Bank syariah memilikikecenderungan untuk membentuk penyisihan kerugian untuk menyerap kerugian di masa depan (Boulilaet al. 2010). Bank Indonesia melalui PBI No 5/9/2003 tentang Penyisihan Penghapusan Aktiva Produktif (PPAP) bagi bank syariah mewajibkan bank syariah membuat PPAP. PPAP dibentuk sebesar (1) $5 \%$ dari aset produktif yang digolongkan dalam perhatian khusus, (2) 15\% dari aset produktif yang digolongkan kurang lancar setelah dikurangi nilai agunan, (3) 50\% dari aset produktif yang digolongkan diragukan setelah dikurangi nilai agunan dan (4) 100\% dari aset produktif yang digolongkan macet setelah dikurangi nilai agunan.

Pengalaman dalam menjalankan usaha bagi bank akan mempengaruhi keberadaan bank dalam menghadapi persaingan. Farook dkk.(2009) memasukkan variabel ini menjadi variabel independen dalam penelitiannya. Cara mengukur variabel ini adalah dengan menghitung selisih dari bulan berdirinya bank hingga September 2011 sebagai periode akhir penelitian. Umur bank menggunakan satuan bulan, rumus (9).

Tabel 1. Rumus

Asset spread $=\mid(\mathrm{ROA}$ - average ROIAH $) \mid$

average $\mathrm{ROIAH}=\frac{\text { pendapatan yang harus dibagi }}{\text { saldo rata-rata instrumen bagi hasil deposan }}$

Capital Adequacy Ratio CAR $=\frac{\text { Modal Bank }}{\text { Total ATMR }} \times 100 \%$

Financing to Deposit Ratio $=\frac{\text { Total pembiayaan }}{\text { Total Dana Pihak Ketiga }} \times 100 \%$

Non Performing Financing NPF $=\frac{\text { Total Pembiayaan bermasalah }}{\text { Total Pembiayaan }} \times 100 \%$

$\mathrm{PPDB}=\mathrm{PDBt}-\mathrm{PDBt}-1$

Loan Asset to Total Asset LATA $=\frac{\text { Loan Asset }}{\text { Total Asset }}$

$P D P K=\frac{\text { Dana Pihak Ketiga }}{\text { Total Aset }}$

Umur Bank = Bulan dalam Periode Penelitian - Bulan berdirinya bank 


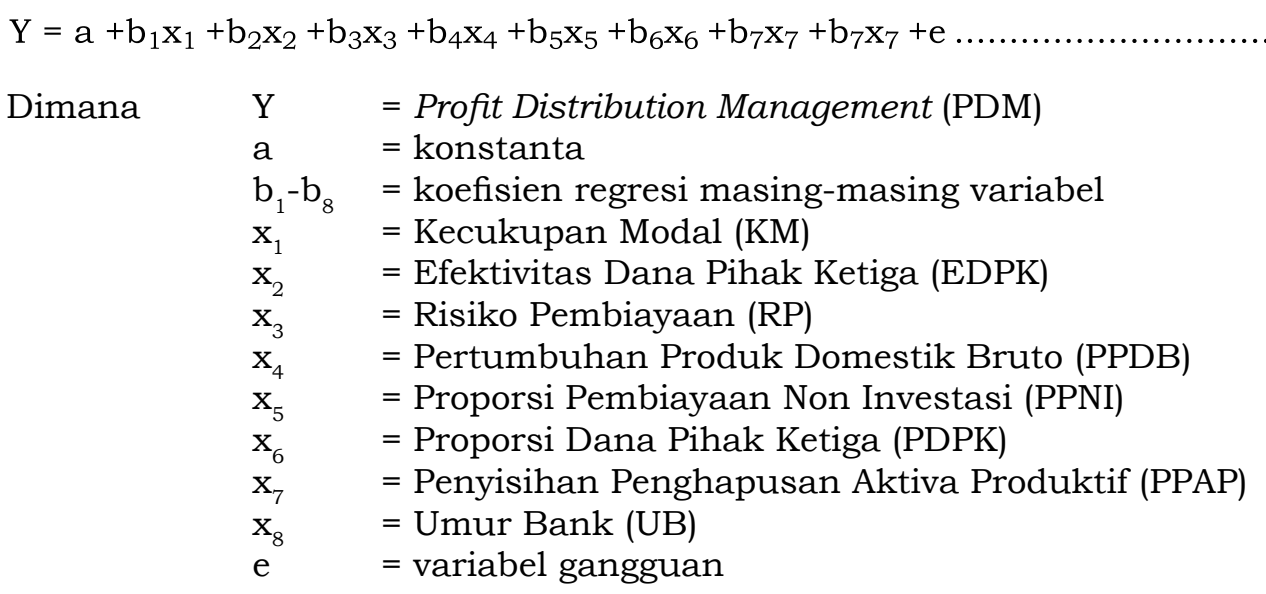

Populasi penelitian ini adalah perbankan syariah di Indonesia periode 2008-2011. Adapun kriteria pemilihan sampel (purposive sampling) sebagai berikut: (1) Bank syariah yang tergolong BUS (Bank Umum Syariah) dan UUS (Unit Usaha Syariah) (2) Bank syariah tersebut menerbitkan laporan keuangan triwulanan pada periode 2008-2011 secara konsisten dan telah dipublikasikan di Bank Indonesia atau pada website masing-masing bank syariah tersebut (3) Bank syariah memiliki data yang dibutuhkan terkait pengukuran variabel-variabel yang digunakan untuk penelitian selama periode 2008-2011. Model persamaannya seperti dalam rumus (10)

\section{HASIL DAN PEMBAHASAN}

Objek penelitian yang digunakan dalam penelitian ini adalah perusahaan perbankan yang terdaftar di direktori Bank Indonesia pada periode triwulan IV tahun 2008 hingga triwulan III tahun 2011. Pemilihan sampel dalam penelitian ini ditentukan dengan menggunakan metode purposive sampling dengan beberapa ketentuan. Diperoleh sampel sejumlah 56 .

Hasil analisis statistik deskriptif menunjukkan bahwa dari 56 buah sampel data PDM, nilai minimum sebesar 0,01 terdapat pada Bank Mega Syariah triwulan dua tahun 2009 dan maksimum sebesar 4,29 pada Bank Muamalat triwulan tiga tahun 2009. Sedangkan nilai rata-rata sebesar 0,7944 dengan standar deviasi sebesar 0,72541. Dari 56 buah sampel data KM, nilai minimum sebesar 10,12 ada pada Bank Muamalat triwulan 2 tahun 2010 dan maksimum sebesar 45,27 pada Bank BRI Syariah triwulan 1 tahun 2009. Sedangkan nilai rata-rata sebesar 15,6037 dengan standar deviasi sebesar 7,23965. Nilai minimum sebesar $10,12 \%$ memenuhi persyaratan dari PBU No: 10/15/PBI/2008 Tentang Kewajiban Penyediaan Modal Minimum, bahwa bank wajib menyediakan modal minimum sebesar $8 \%$.

Tabel 2 Sampel Penelitian Periode 2008 - 201

\begin{tabular}{lc}
\hline \multicolumn{1}{c}{ Kriteria Sampel } & $\begin{array}{c}\text { Jumlah } \\
\text { Perbankan }\end{array}$ \\
\hline $\begin{array}{l}\text { Bank syariah yang tergolong Bank Umum Syariah (BUS) dan } \\
\text { Unit Usaha Syariah (UUS) dan terdaftar di Bank Indonesia }\end{array}$ & 34 \\
Tidak tersedia laporan triwulanan lengkap selama periode & $(29)$ \\
triwulanan IV 2008 hingga triwulanan III 2011 & 5 \\
Bank syariah memiliki laporan keuangan yang dibutuhkan & \\
untuk penelitian selama periode triwulanan IV 2008 hingga & \\
triwulanan III 2011 & 60 \\
Sampel penelitian (triwulan IV 2008 hingga triwulan III & \\
2011) & $(4)$ \\
Sampel yang memiliki data outlier & 56 \\
\hline Sampel penelitian yang digunakan & \\
\hline
\end{tabular}

Sumber: Data sekunder yang diolah, 2012 
Nilai minimum EDPK adalah 65,96 ada pada Bank Muamalat triwulan 2 tahun 2009 dan maksimum sebesar 183,25 pada Bank BRI Syariah triwulan 2 tahun 2009. Sedangkan nilai rata-rata sebesar 94,5421 dengan standar deviasi sebesar 18,76734.

Nilai minimum RP adalah 1,32 ada pada Bank Bukopin Syariah triwulan 2 tahun 2011 dan maksimum sebesar 8,86 pada Bank BRI Syariah triwulan 1 tahun 2009. Sedangkan nilai rata-rata sebesar 3,8468 dengan standar deviasi sebesar 1,58354 .

Diketahui data PPDB, nilai minimum sebesar 7,68 ada pada triwulan 4 tahun 2010 dan maksimum sebesar 14,37 pada triwulan 1 tahun 2011. Sedangkan nilai ratarata sebesar 11,5149 dengan standar deviasi sebesar 1,98698. Nilai minimum PPNI sebesar 12,59 ada pada Bank Bukopin Syariah triwulan 3 tahun 2011 dan maksimum sebesar 3085,49 pada Bank Muamalat triwulan 3 tahun 2009. Sedangkan nilai rata-rata sebesar 159,6423 dengan standar deviasi sebesar 405, 11494 .

Nilai minimum PDPK sebesar 26,70 ada pada Bank Bukopin Syariah triwulan 1 tahun 2009 dan maksimum sebesar 77,45 pada Bank Muamalat triwulan 2 tahun 2009. Sedangkan nilai rata-rata sebesar 64,5918 dengan standar deviasi sebesar 12,24004.

PPAP memiliki nilai minimum sebesar 5,91 ada pada Bank Mega Syariah triwulan 4 tahun 2008 dan maksimum sebesar 13,86 pada Bank Mandiri Syariah triwulan 1 tahun 2011. Sedangkan nilai rata-rata sebesar 9,9964 dengan standar deviasi sebesar 1,81515. Pada data UB, nilai minimum sebesar 2,00 ada pada Bank Bukopin Syariah triwulan 4 tahun 2008 dan maksimum sebesar 235,00 pada Bank Muamalat triwulan 2 tahun 2011. Sedangkan nilai rata-rata sebesar 92,1250 dengan standar deviasi sebesar 75,67492 .

Dari hasil pengujian normalitas dengan uji Kolmogorov-Smirnov, diketahui besarnya signifikan berada di atas 0,05 atau 5\%, yaitu 0,993. Dengan demikian dapat disimpulkan bahwa nilai seluruh variabel memiliki distribusi normal.

Hasil uji Durbin Watsonmenunjukkan nilai DW sebesar 1,918. Nilai DW akan dibandingkan dengan nilai tabel dengan menggunakan derajat kepercayaan 95\%, dengan jumlah sampel 56 dengan 8 variabel independen. Dari uji Durbin Watson didapatkan nilai dU 1,909. Nilai test DW berada pada $1,909>1,918<2,091$, sehingga model dikatakan lolos uji autokorelasi.

Nilai VIF tidak ada yang $\geq 10$ dan nilai tolerancetidak ada yang $\leq 0,10$, maka dapat dinyatakan bahwa dalam penelitian ini tidak terjadi gejala multikolinearitas. Dalam uji Glejser, apabila variabel signifikan di bawah 0,05 maka dapat dinyatakan bahwa model mengandung heteroskedastisitas. Dapat disimpulkan bahwa model tidak mengandung heteroskedastisitas karena tingkat signifikansi variabel di atas 0,05 atau dengan kata lain model mengandung homoskedastisitas. Kesimpulannya adalah penelitian dinyatakan lolos uji heteroskedastisitas.

Berdasarkan hasil perhitungan F-hitung, diketahui pada persamaan pertama diperoleh nilai F-hitung sebesar 10,535 dengan probabilitas 0,000 . Karena probabilitas lebih kecil dari 0,05 maka dari model regresi adalah fit atau dapat dikatakan bahwa KM, EDPK, RP, PPDB, PPNI, PDPK, PPAP dan UB mempunyai pengaruh terhadap Profit Distribution Management (PDM) bank. Diperoleh persamaan regresi seseperti dalam rumus (11).

Besarnya nilai adjusted $R^{2}$ dalam model regresi bank umum syariahdiperoleh sebesar 0,581. Hal ini menunjukkan bahwa besar kemampuan menjelaskan variabel independen yaitu KM, EDPK, RP, PPDB, PPNI, PDPK, PPAP dan UB terhadap variabel dependen (PDM) yang dapat diterangkan oleh model persamaan ini sebesar $58,1 \%$ sedangkan sisanya sebesar $41,9 \%$ dipengaruhi oleh faktor-faktor lain yang tidak dimasukkan dalam model regresi.

Berdasarkan output SPSS, hasil penelitian menunjukkan bahwa variabel kecukupan modalberpengaruh positif terhadap profit distribution management (PDM), sehingga $\mathrm{H}_{1}$ dapat diterima. Jadi semakin tinggi $\mathrm{KM}$ suatu bank dapat menjadi tolak ukur peningkatan PDM.

Variabel efektivitas dana pihak ketiga berpengaruh negatif terhadap PDM. Hal ini berartisemakin efektif dana pihak ketiga dikelola, kecenderungan manajemen distri-

$\mathrm{PDM}=1,094+0,34 \mathrm{KM}-0,13 \mathrm{EDPK}+0,32 \mathrm{RP}-0,54 \mathrm{PPDB}+0,001 \mathrm{PPNI}-$ 
Tabel 3. Koefisien Determinasi

\begin{tabular}{cccccc}
\multicolumn{8}{c}{ Model Summary $^{\mathbf{b}}$} \\
\hline Model & $\mathrm{R}$ & R Square & $\begin{array}{c}\text { Adjusted R } \\
\text { Square }\end{array}$ & $\begin{array}{c}\text { Std. Error of } \\
\text { the Estimate }\end{array}$ & $\begin{array}{c}\text { Durbin- } \\
\text { Watson }\end{array}$ \\
\hline 1 & $.801^{\mathrm{a}}$ & .642 & .581 & .46953 & 1.918 \\
\hline
\end{tabular}

Sumber: Data sekunder yang diolah, 2012

busi laba yang mengacu pada bunga bank konvensional semakin mengecil. Risiko pembiayaan tidak berpengaruh terhadap PDM. Hasil tersebut menunjukkan bahwa semakin tinggi RP suatu bank tidak menjadi tolak ukur adanya aktivitas peningkatan PDM oleh manajer bank yang bersangkutan. Bank Indonesia melalui Surat Edaran Bank Indonesia No.6/23/DPNP tanggal 31 Mei 2004 menetapkan kriteria rasio NPL yang ideal di bawah $6 \%$. Berdasarkan data statistik deskriptif, rata-rata RP berada pada nilai 3.84. Nilai tersebut dibawah angka $6 \%$, yang berarti telah memenuhi kriteria Bank Indonesia. Dengan demikian dapat dikatakan bahwa tingkat RP yang masih ideal menyebabkan RP tidak berpengaruh terhadap PDM.

Hasil pengolahan datamembuktikan Produk Domestik Bruto sebagai alat ukur pendapatan negara tidak dapat menjadi refleksi atau cerminan keadaan keuangan secara sempurna pada tiap bank dalam suatu Negara. Hasil penelitian ini sesuai dengan penelitian Farooket al. (2009) bahwa Growth of Gross Domestic Product tidak berpengaruh terhadap PDM. Proporsi pembiayaan non investasi berpengaruh positif terhadap PDM. Oleh karena itu $\mathrm{H}_{5}$ dapat diterima. Hasil penelitian ini sesuai dengan penelitian $\mathrm{Fa}$ rook et al. (2009) yang menyatakan bahwa rasio Loan Asset to Total Asset(LATA) berpengaruh positif terhadap PDM.

Hasil pengujian mengindikasikan jika proporsi dana pihak ketiga meningkat maka aktivitas manajer untuk melakukan PDM akan menurun. Hal tersebut berlawanan dengan rumusan hipotesis. Hasil penelitian ini sesuai dengan hasil penelitian terdahulu yang dilakukan oleh Farook et al.(2009), bahwa variabel DEPOSIT (PPDK) dalam penelitiannya berpengaruh negatif terhadap PDM.Farook berpendapat bahwa hal tersebut dapat terjadi ketika bank syariah berada dalam kondisi Pasar Persaingan Monopolistik (PPM). Beberapa penelitian dari Indonesia tentang jenis struktur pasar di industri perbankan menemukan bahwa industri perbankan Indonesia memiliki struktur pasar berupa PPM (Setiyowati 2005; Yani dan Lyla 2006 dan Syafri 2007). Dalam bentuk persaingan ini, terdapat banyak penjual dimana masing-masing penjual memiliki kekuatan pasar. Hal ini karena barang yang ada dalam pasar tersebut adalah barang yang sudah mengalami diferensiasi, atau dengan kata lain barang yang ada bukan barang substitusi sempurna (Rahayu 2011). Karena perbedaan dan ciri khas dari suatu barang, konsumen tidak akan mudah berpindah ke merek lain dan tetap memilih merek tersebut walaupun penjual menaikkan harga.

Berdasarkan hasil pengolahan data, diketahui bahwa penyisihan penghapusan aktiva produktif (PPAP) berpengaruh positif terhadap PDM. Hasil pengujian mengindikasikan jika PPAP meningkat, maka PDM juga akan meningkat. Hasil penelitian ini sesuai dengan penelitian Farook, et al (2009) yang menyatakan bahwa discretionary reserves berpengaruh positif terhadap PDM.

Penelitian ini menemukan hasil bahwa umur bank tidak berpengaruh terhadap PDM, sehingga mengidikasikan bahwa semakin tinggi umur suatu bank tidak mampu menjadi tolak ukur adanya aktivitas peningkatan PDM oleh manajer bank yang bersangkutan. Aktivitas PDM lebih condong dilakukansebagai hasil daridecision making yang dibuat manajer atas kondisi keuangan bank dan market.

\section{SIMPULAN}

Berdasarkan hasil analisis data dan pembahasan yang sudah diuraikan, dapat ditarik kesimpulan sebagai berikut: (1)Kecukupan modal, proporsi pembiayaan non investasi dan penyisihan penghapusan aktiva produktif secara parsial berpengaruh positifterhadap profit distribution management;(2)Efektivitas dana pihak ketiga dan proporsi dana pihak ketiga secara parsial berpengaruh negatif terhadap profit distri- 
bution management;(3)risiko pembiayaan, pertumbuhan produk domestik bruto dan umur bank secara parsial tidak berpengaruh terhadap profit distribution management.

Keterbatasan dalam penelitian ini adalah: (1)Kemampuan prediksi yang dilihat dari nilai adjusted $R$ Square sebesar 58,1\% berarti 41,9\% dipengaruhi oleh faktor-faktor lain diluar variabel yang diteliti. (2)Penelitian ini menggunakan bank syariah yang terdaftar di Bank Indonesia pada periode triwulan IV 2008 hingga triwulan III 2011 sebanyak 11 BUS dan 23 UUS, namun hanya 5 bank yang tergolong BUS saja yang konsisten menerbitkan laporan keuangan triwulanan. Jadi bank yang menjadi sampel dan dijadikan penelitian hanya 20 bank.

Adapun implikasi dari penelitian ini adalah: (1)bagi manajemen bank syariah, penelitian ini diharapkan dapat menjadi bahan pemikiran untuk mengembangkan produk berbasis bagi hasil yang lebih murni syariah. (2)bagi pengembangan ekonomi syariah, penelitian ini diharapkan dapat menjadi benih bagi studi yang lebih intensif untuk menyempurnakan penerapan sistem bagi hasil yang lebih baik sesuai syariah. (3) bagi deposan diharapkan dapat lebih mengenal karakteristik bank syariah terutama deposan beragama Islam,sehingga arah segmen dapat berubah dari floating segment menuju shariah loyalist. Saran yang dapat diberikan bagi penelitian mendatang adalah: (1)penelitian selanjutnya menggunakan variabel-variabel internal perusahaan lain sebagai variabel independen, misalnya: rasio BOPO, NIM, ukuran perusahaan. Selain itu dapat digunakan variabel-variabel eksternal perusahaan, misalnya: tingkat inflasi,tingkat suku bunga bank, BI Rate, dan lain-lain. (2) Penelitian selanjutnya diharapkan dapat menggunakan sampel yang lebih banyak dan tahun pengamatan yang lebih lama.

\section{DAFTAR RUJUKAN}

Aisiyah, S. 2010. "Faktor-Faktor Yang Mempengaruhi Bagi Hasil Pada Bank Syariah Mandiri”. Skripsitidak dipublikasikan. UIN Sunan Kalijaga.

Andriyanti, A. dan Wasilah. 2010. "FaktorFaktor yang Mempengaruhi Jumlah Penghimpunan Dana Pihak Ketiga Bank Muamalat Indonesia".

Antonio, M. S. 2001. Bank Syariah dari Teori Ke Praktek. Jakarta : Gema Insani Pers-Tazkia.
Azmy, M. S. 2009. "Analisis Faktor-Faktor Yang Mempengaruhi Tingkat Bagi Hasil Simpanan Mudharabah Pada Bank Umum Syariah Di Indonesia”. Skripsitidak dipublikasikan. UIN Sunan Kalijaga.

Boulila dkk. 2010. "Do Islamic Banks Use Loan Loss Provisions to Smooth Their Results?".

Brooks, L.J. 2004, Business and Professional Ethics for Directors, Executives, and Accountants. 3th ed. Thomson South Western

Farook dkk., 2009. "Profit Distribution Management Management By Islamic Banks: An Empirical Investigation".

Karim, A. Dan Afif. 2006. Islamic Banking Behaviour in Indonesia: a Qualitative Approach.

Karim, A. 2003. Bank Islam :Analisis Fiqh dan Keuangan, ed 2. Jakarta : Raja Grafindo Persada.

Khairunnisa, D. 2001. Preferensi Masyarakat Terhadap Bank Syariah (Studi Kasus Bank Muamalat Indonesia dan BNI Syariah). Makalah pada Simposium Nasional. Yogyakarta. Sistem Ekonomi Islam, P3EI-FEUII.

Mangkuto, I.J. 2004. "Pengaruh Tingkat Suku Bunga Deposito Bank Konvensional dan Tingkat Pendapatan Deposito Mudharaba Terhadap Pertumbuhan Deposito di Bank Muamalat. Tesis tidak dipublikasikan. UI.

Mawardi, N. 2005. "Faktor-Faktor Yang Mempengaruhi Penetapan Return Bagi Hasil Deposito MudharabahMuthlaqah". Tesis tidak dipublikasikan. UI.

Muhammad. 2005. Manajemen Bank Syariah. Yogyakarta : UPP AMP YPKN.

Nasution, A. W. 2009. "Pengaruh pertumbuhan variabel ekonomi makro dan equivalent rate terhadap pertumbuhan aset perbankan syariah di Indonesia”. Tesistidak dipublikasikan.UI.

Setiyowati, R. 2005. "Tingkat Persaingan Industri Perbankan di Indonesia". Tesistidak dipublikasikan. Pascasarjana FEUI.

Syafri, Y. 2007. "Estimasi Tingkat Persaingan dalam Industri Perbankan Indonesia: Pendekatan Panzar-Rosse Model. Tesis tidak dipulikasikan. UI.

Tobing, W.R.L dan N.I. Anggorowati. 2009. Membentuk PPAP untuk menutup risiko kerugian yang mungkin timbul dari penanaman dana. Asian Banking and Finance Informatic Institute Perbanas. 
Vustany, R.O. 2006. "Faktor-Faktor Yang Mempengaruhi Pemberian Bagi Hasil Nasabah". Tesis tidak dipublikasikan. UI.
Yani, S. dan Lyla. 2006. "Persaingan Perbankan di Indonesia."Buletin Ekonomi. 